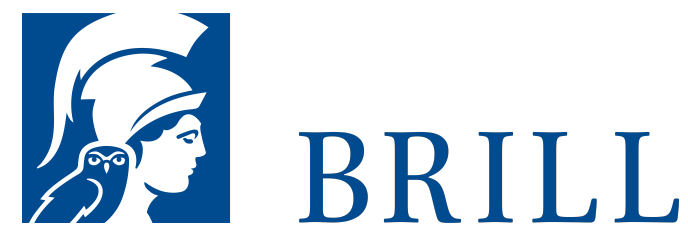

\title{
The Forgotten Film Adaptations of D.H. Lawrence's Short Stories
}

Author: Jason Mark Ward

This book looks beyond fidelity to emphasize how each adaptation of D.H. Lawrence's short stories functions as a creative response to a text, foregrounding the significance of its fluidity, transtextuality, and genre. The adaptations analysed range from the first to the most recent and draw attention to the fluidity of textual sources, the significance of generic conventions and space in film, the generic potentialities latent within Lawrence's tales, and the evolving nature of adaptation. By engaging with recent advances in adaptation theory to discuss the evolving critical reception of the author's work and the role of the reader, this book provides a fresh, forwardlooking approach to Lawrence studies.

\section{Readership}

All interested in D.H. Lawrence's short stories, adaptation studies, short films of literary sources, television adaptations, modernism on film, or the connections between adaptation, genre studies and the fluid text.

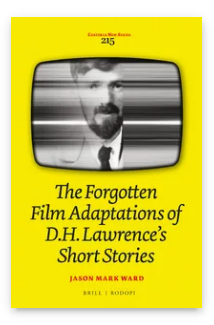

Pages: Approx. 250 pp. 34 color ill.

Language:

English

Subjects:

Criticism \&

Theory,

Literature and

Cultural Studies,

English \&

Anglophone,

Literature and

Cultural Studies,

Drama \&

Theatre Studies,

Art History,

Literature, Arts

\& Science,

Literature and

Cultural Studies

Publisher: Brill

Series:

Costerus New

Series Online,

Volume: $\mathbf{2 1 5}$

Costerus New

Series, Volume:

215

E-Book (PDF)

Released online:

11 Jul 2016

ISBN: 978-90-

04-30905-O 
Jason Mark Ward, PhD. Nottingham University, is a Lecturer in literature at Hacettepe University. He has published and presented on literature, adaptation and pedagogy, including The Oscars: Five Filmic Readings of The Rocking-Horse Winner.

For more information see brill.com

Hardback

Publication date:

14Jan 2016

ISBN: $978-90-$

04-30904-3

List price

USD \$121.0o

Order information: Order online at brill.com +44330 3330049 | customerservices@brill.com Submission information: brill.com/authors

Titles published by Brill | Fink, Brill | mentis or Brill | Schöningh: +49(o)71 5413279216 | brill@brocom.de 